\title{
Techno-Economic Analysis of Healthy Herbal Ice Cream Product
}

\author{
Misri Gozan ${ }^{1 *}$, Muhammad Yusuf Arya Ramadhan ${ }^{1}$, Andre Fahriz Perdana Harahap ${ }^{1}$, \\ Cut Nanda Sari ${ }^{1}$, Yuswan Muharam ${ }^{1}$, Widodo Wahyu Purwanto ${ }^{1}$, Dewi Tristantini ${ }^{1}$ \\ ${ }_{1}^{1}$ Department of Chemical Engineering, Faculty of Engineering, Universitas Indonesia, Kampus UI Depok, Depok \\ 16424, Indonesia
}

\begin{abstract}
Gynura procumbens (longevity spinach) is typically used in Asian folk medicine to treat inflammation and rheumatism. Studies show that Gynura procumbens has many applications, especially as a therapeutic medicine for antimicrobial, anti-inflammatory, antioxidant, organ protective, antihyperglycemic, antihypertensive, cardioprotective, anti-cancer, and fertility enhancement. The consumption of ice cream in Indonesia is increasing each year. Most consumers perceive ice cream as a sweet treat, with indulgence the most important trend in the market. Adding herbal ingredients to ice cream can address several consumer problems, such as high sugar intake, and provide the health benefits of herbals with ease of consumption. This study examines the techno-economic analysis of a healthy herbal ice cream product that can not only provide herbals in a trendy mode of consumption but can also address the problems that occur from consuming ice cream. The formulation of the supplement consists of longevity spinach $5 \%$, skim milk $69.75 \%$, extract flavor $0.6 \%$, sugar $3.25 \%$, salt $1 \%$, lecithin $20 \%$, and food coloring $0.4 \%$. The manufacturing process consists of a typical ice cream production line with Gynura procumbens pretreatment at the start. The plant designed will produce 57,734 jars per day with a price of Rp 5,066 for each jar. The capital investment of our plant is Rp 10,305,160,564. We gain Rp 77,216,401,229 per year, with IRR as high as $46 \%$. Our NPV is Rp 21,819,500,900 with a payback period of 2.24 years. Our product is relatively sensitive to the selling price and the price of the raw materials.
\end{abstract}

Keywords: Flavonoid; Gynura procumbens; Herbal; Ice cream; Polyphenols

\section{Introduction}

Ice cream is a mixture of mainly dairy ingredients and ingredients for sweetening and flavoring, such as fruits, nuts, and chocolate chips. American-style ice creams are churned quickly to whip in plenty of air. The air portion of the product is called overrun, held by the high proportion of cream in the base. Most luxury ice creams have an overrun of around $25 \%$, which means they have increased the mix in volume by $25 \%$. Cheaper commercial versions can run from $50 \%$ to over $90 \%$, which gives them a light, thin, fast-melting texture with fewer flavors (Morelli's Gelato, 2017). The ice cream market in Indonesia forecasted growth at a compound annual growth rate (CAGR) of 7.8\% during 2014-2019 (Canadean, 2015). The volume consumption of ice cream products has reached 158 million $\mathrm{kg}$ in 2018 and forecasted to grow by $16 \%$ per year until 2020 with the market value reached Rp19.8 trillion (Ciptadana Sekuritas Asia, 2018).

However, ice cream can harm health for several reasons. First, it has a high sugar content, and up to 12 to $16 \%$ of its compositions are sweeteners such as sucrose and corn

${ }^{*}$ Corresponding author's email: mrgozan@gmail.com, Tel.: +62-857-81176292 doi: 10.14716/ijtech.v11i5.4327 
syrup. Second, it also has a high fat content: in some cases, ice cream contains $16 \%$ fat. Third, the lack of fiber in ice cream can lead to constipation and weight gain. Finally, the usage of additives such as preservatives, artificial flavoring, and artificial coloring can lead to an allergic reaction of the consumer, and the chemical compounds can accumulate inside the body (Marshall et al., 2012).

Longevity spinach (Gynura procumbens) is an evergreen shrub found abundantly in tropical Asia, especially Indonesia, Thailand, and Malaysia, which is of considerable medicinal and culinary value but is still mostly unknown outside those regions (Mou and Dash, 2016). Longevity spinach's beneficial properties have been attributed to bioactive compounds such as flavonoids, unsaturated sterols, triterpenoid, polyphenols, glycosides, and the many essential oils in this plant (Sudarto and Pramono, 1985). Longevity spinach extract has resulted in a significant decrease in heart rate which help reduce the effect of hypertension. It shown a strong negative chronotropic effect in rats' right atria and adverse ionotropic effects in rats' left atria (Hoe et al., 2011; Kaur et al., 2012; Abrika et al., 2013). The antioxidant activity of Longevity spinach extracts was evaluated by 2,2-diphenyl-1picrylhydrazyl (DPPH) assay to measure its free radical scavenging. In a comparative study, longevity spinach extract exhibited the highest percentage of DPPH inhibition (52.81\%) compared to various other plant extracts (Maw et al., 2011). Longevity spinach is commonly used to treat inflammation. It has been proven to prevent the increase in ear thickness in mice caused by croton oil-induced inflammation (Iskander et al., 2002).

This study aims to design a plant to produce healthy herbal ice cream as a highly nutritious product and healthier snacking alternative, to improve public health. The study was carried out by formulating the product using information obtained from a customer survey and from the international food regulations of the U.S. Food and Drug Administration. The complete composition of the healthy herbal ice cream product can be seen in Table 1. The nutritional value of the final product can be seen in Table 2.

Table 1 Composition of healthy herbal ice cream

\begin{tabular}{lcc}
\hline \multicolumn{1}{c}{ Ingredient(s) } & Amount $(\mathrm{g})$ & Composition (\% total amount) \\
\hline Longevity spinach & 10 & 5 \\
Skim milk & 139.5 & 69.75 \\
Lemon or vanilla & 1.2 & 0.6 \\
extract & 6.5 & 3.25 \\
Glucose & 2 & 1 \\
Salt & 40 & 20 \\
Lecithin (eggs) & 0.8 & 0,4 \\
Food coloring & 200 & 100 \\
Total &
\end{tabular}

Table 2 Nutritional value of healthy herbal ice cream

\begin{tabular}{lrl}
\hline \multicolumn{1}{c}{ Specification } & Value & \multicolumn{1}{c}{ Reference } \\
\hline Fat & 5.6 & Guinard et al., 1996 \\
Carbohydrate & 10.8 & Chou and Tobias, 1960 \\
Dietary fiber & 5 & Soukoulis et al., 2009 \\
Sugar & 4.6 & Guinard et al., 1996 \\
Protein & 12.8 & Patel et al., 2006 \\
Vitamin A & 0.00064 & \\
Calcium & 0.00098 & \\
Vitamin D & 0.00016 & \\
Vitamin B-12 & 0.00062 & \\
Vitamin C & 0.0002 & \\
\hline
\end{tabular}




\section{Methods}

The research is done by designing a product, synthesizing and simulating the process needed in order to define process parameters and economic parameters for the technoeconomic analysis (Rosyidi et al., 2016; Kusrini and Kartohardjono, 2019). The process synthesized in this study has gone through a selection process where various extraction methods and ice-cream-making methods were scored. After the selection, the chosen methods were integrated into the main block flow diagram (Figure 1) and Process flow diagram (Figure 2). There are six main processes in the production of healthy herbal ice cream: grinding, leaching of Gynura procumbens as the primary source nutrient, blending of the herbal extract with ice cream premix, homogenizing of the mixture, cooling of the mixture to below room temperature, and finally packaging of the final product, which consists of jar filling and packaging to boxes. The final product will be stored in freezer storage to freeze the ice cream.

The Gynura procumbens is washed to guarantee hygiene. This process operates at ambient temperature. Water and ash are the residues of the washing process. The wastewater is then separated from the raw material. There are two output streams from this process: wastewater and cleaned Gynura procumbens. The clean Gynura procumbens is then transferred into the grinding process. The raw material is ground into smaller pieces. The most crucial goal of the process is to reduce the size of the material from discrete to bulk flow, to ease the extraction of the active herbal compound. The ground Gynura procumbens is then extracted using solid-liquid extraction by leaching in a mixer-settler extractor. Water is the primary solvent of this process to ensure the halal aspect of the product. The extract is then blended with other materials, such as milk, flavoring, emulsifier, and air, and mixed into an almost homogenous mixture. Milk cannot be blended homogeneously because the forming milk clots out of the fat content. Therefore, we used high-pressure homogenization to homogenize the milk in the mixed compound. To produce cooled ice cream and maintain the product's air content, we use a freeze-thaw module to decrease the temperature in our product. The cooled mixture is then filled into a plastic jar using a filling machine, and it is packed per unit in cardboard. The mass and energy balance are calculated using SuperPro Designer v9.0.

This healthy herbal ice cream plant will be built in a large-scale factory located in Jl. Raya Parung, Bogor District, West Java, Indonesia, occupying approximately 5,100 $\mathrm{m}^{2}$.

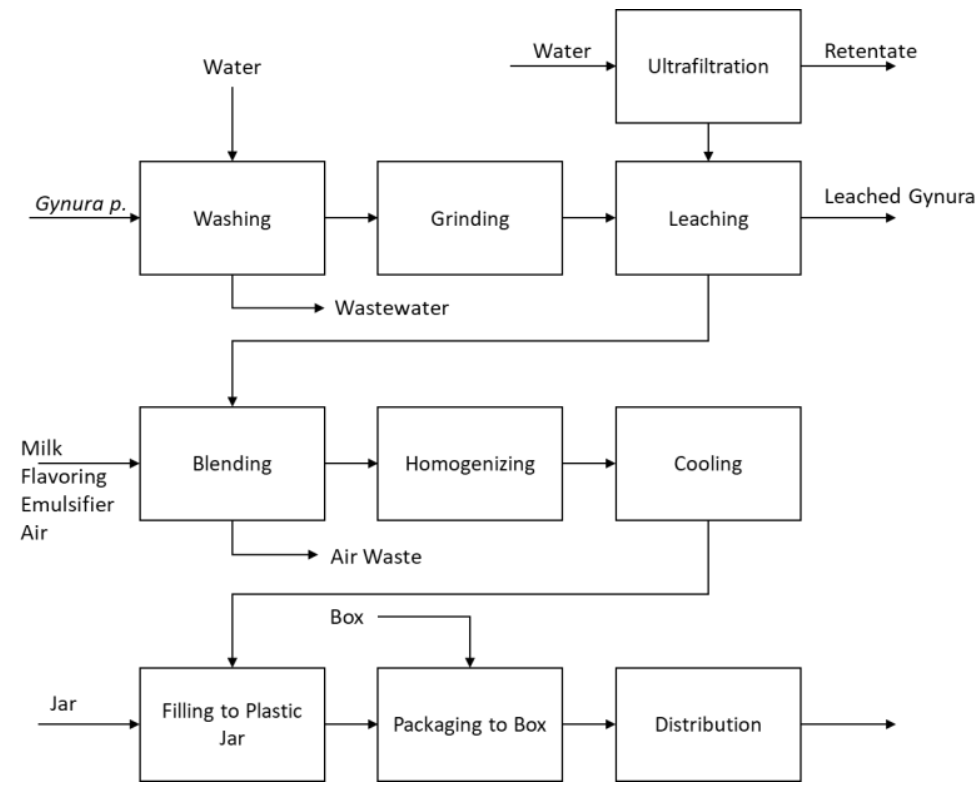


Figure 1 Block flow diagram of healthy herbal ice cream production

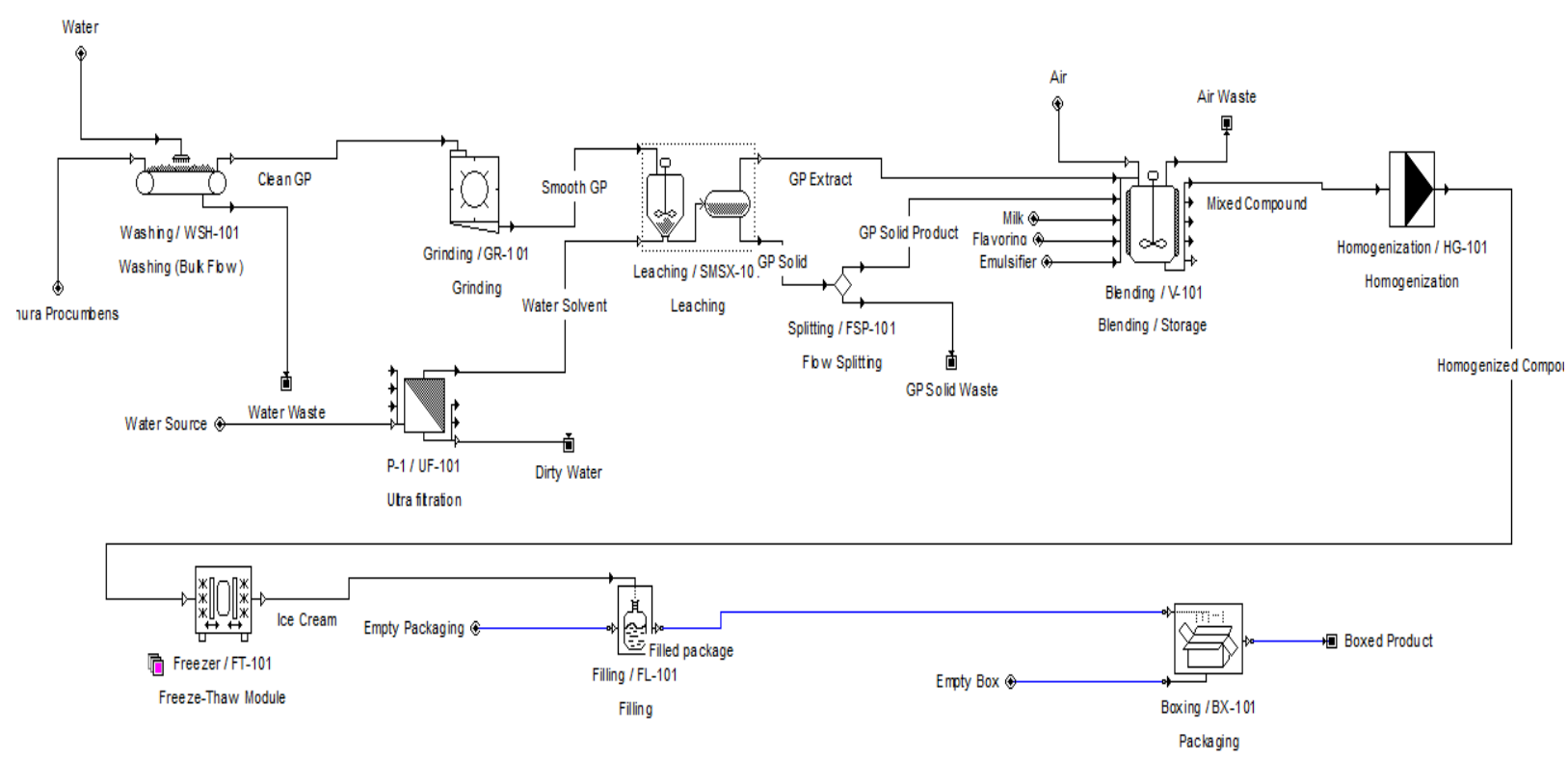

Figure 2 Process flow diagram of healthy herbal ice cream production

\section{Results and Discussion}

\subsection{System Performance Benchmark}

Based on a selection process carried out previously, we carried out the technical design of the equipment we used. In this research, we choose to design nine key pieces of equipment for the whole process: washer, grinder, ultrafiltration unit, solids mixer-settler extractor, blending tank, high-pressure homogenizer, freeze-thaw module, jar filler, and box packer. We calculate the specification using SuperPro Designer v9.0, as used in several preliminary designs of plant research (Surya et al., 2018; Harahap et al., 2019; Hidayat et al., 2019). The results are presented in Table 3.

Table 3 Technical specification of main production equipment

\begin{tabular}{lcccrrr}
\hline Equipment & $\begin{array}{c}\text { Flow Rate } \\
(\mathrm{kg} / \mathrm{batch})\end{array}$ & $\begin{array}{c}\text { Temperature } \\
\left({ }^{\circ} \mathrm{C}\right)\end{array}$ & $\begin{array}{c}\text { Power } \\
\text { Consumption } \\
(\mathrm{kW} / \mathrm{batch})\end{array}$ & $\begin{array}{r}\text { Length } \\
(\mathrm{mm})\end{array}$ & $\begin{array}{r}\text { Width } \\
(\mathrm{mm})\end{array}$ & $\begin{array}{c}\text { Height } \\
(\mathrm{mm})\end{array}$ \\
\hline Washer & 100 & 28 & 0.633 & 4,034 & 1,689 & 1,718 \\
Grinder & 100 & 28 & 3.546 & 1,030 & 900 & 1,100 \\
Ultrafiltration unit & 810 & 28 & 8.625 & 1,050 & 800 & 1,320 \\
Solids mixer- & 750 & 70 & 2.179 & 2,000 & 2,000 & 2,500 \\
settler extractor & 1,146 & 28 & 27.408 & 840 & 840 & 1,000 \\
Blender & 1,146 & 28 & 16.316 & 1,000 & 750 & 1,100 \\
High-pressure & & -4 & 75.9 & 500 & 750 & 600 \\
homogenizer & 1,046 & -4 & 2.875 & 1,200 & 1,200 & 1,850 \\
Freezer & 1,197 & -4 & 1.38 & 1,550 & 750 & 1,050 \\
Filler & 1,197 & & & & & \\
Packer & & & & &
\end{tabular}

The total factory area planned for this plant is approximately $5,100 \mathrm{~m}^{2}$. The factory layout and its area distribution can be seen in Figures 3. 


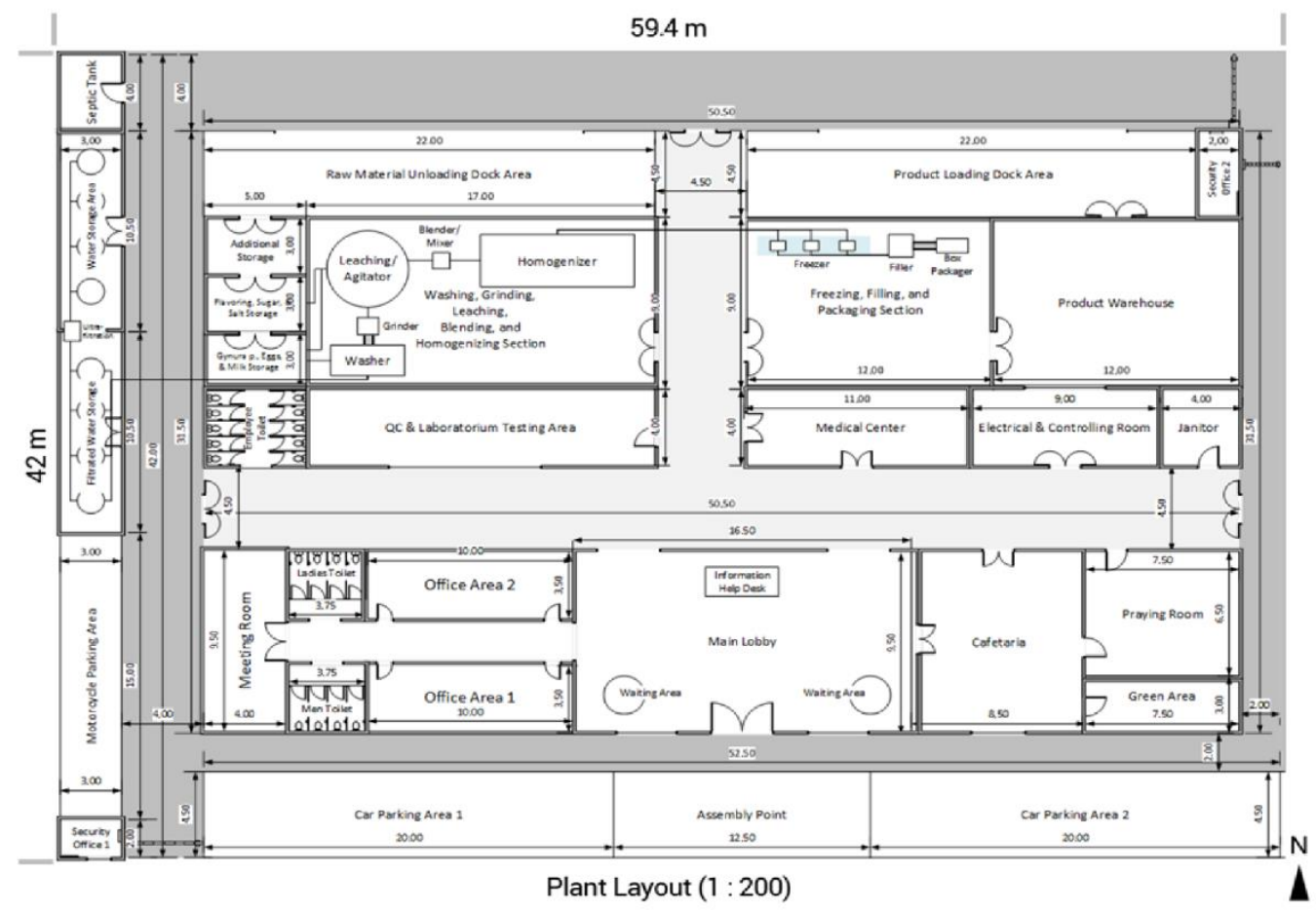

Figure 3 2D plant layout

For the utilities of the plant, we calculate electricity and water requirements. To calculate the electricity requirement of the plant, we sum up the electricity needs in each piece of equipment based on the simulation done in SuperPro and multiply it by 1.25 to allow for line losses and contingencies. The electric power required for this plant is 138.86 $\mathrm{kW} /$ batch for direct power and $54.2 \mathrm{~kW} /$ day for office and supporting facility electricity. With 11 batches per day, the total consumption cost per day in Rupiah is Rp 2,320,770.

The utilization of water in the plant is generally categorized into process water and domestic water. The process water usage is calculated from the amount of water needed in each process. The amount of water required for the process (including in steam form) is $13,323 \mathrm{~kg} /$ day. Meanwhile, the domestic usage of water is calculated from the usage of water for drinking water, toilets, laboratory, mosque, canteen, and gardening. We use USGS's data as the base of this calculation (USGS, 2016). As a result, we obtain a total usage of domestic water of $4000 \mathrm{~kg} /$ day.

The economic analysis of this plant is done by calculating capital expenditure (CAPEX) and operational expenditure (OPEX), which are evaluated using profitability analysis. CAPEX consists of total equipment cost, site development cost, building cost, offsite facilities cost, contingency cost, contractor fees, working capital, supporting facilities, bulk material cost, and additional cost. Total equipment cost was calculated using SuperPro Designer v9.0 with adjustment. The calculation of total CAPEX is shown in Table 4.

The OPEX consists of equity, raw material cost, utility cost, labor cost, maintenance cost, insurance cost, distribution cost, marketing cost, and depreciation. The calculation of OPEX can be seen in Tables 5 to 8. The calculation of income and cash flow is crucial for profitability analysis. Income is determined by the money obtained by selling the product with the deduction of tax and expenses. We predict sales of the product using an integrated supply chain model (Aritonang et al., 2020). Cash flow can be calculated by subtracting outgoings from the income. The cumulative cash flow can be seen in Figure 4. 


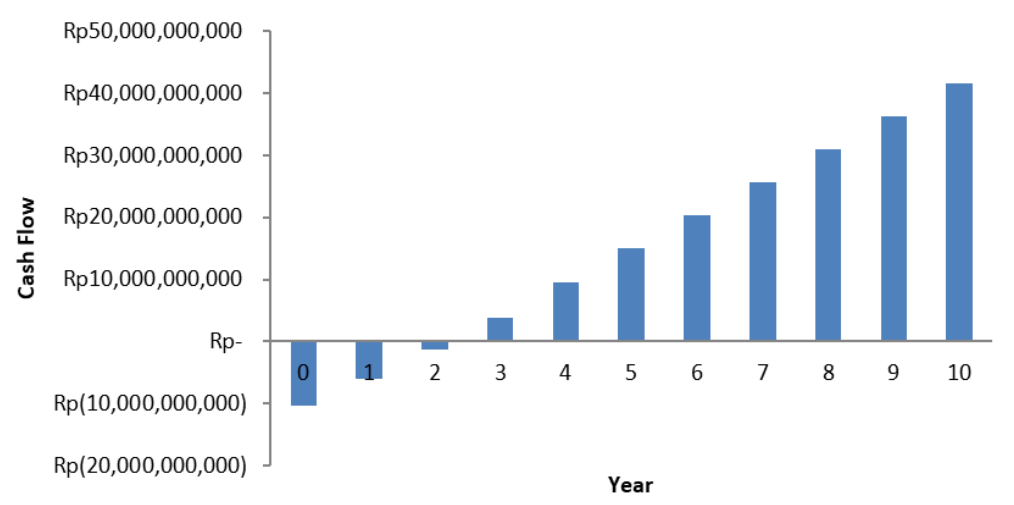

Figure 4 Cumulative cash flow calculation

Table 4 Total capital expenditure calculation

\begin{tabular}{lr}
\hline \multicolumn{1}{c}{ Component } & \multicolumn{1}{c}{ Cost (Rp) } \\
\hline Equipment & $1,546,087,035$ \\
Site Development & $1,995,840,000$ \\
Building & $4,830,750,000$ \\
Offsite Facilities & $186,593,000$ \\
Working Capital & $1,344,151,378$ \\
Contingency & $401,739,151$ \\
\hline Total Capital & $10,305,160,564$ \\
\hline
\end{tabular}

Table 5 Total equity cost to bank (in Rupiah)

\begin{tabular}{crrrrr}
\hline Year & Investment & \multicolumn{1}{c}{ Interest } & $\begin{array}{c}\text { Investment } \\
\text { Payment }\end{array}$ & Payment & $\begin{array}{c}\text { Annual } \\
\text { Payment }\end{array}$ \\
\hline 0 & $7,213,612,394$ & 0 & 0 & 0 & 0 \\
1 & $7,213,612,395$ & $721,361,239$ & $721,361,239$ & $1,442,722,479$ & $1,118,109,921$ \\
2 & $6,492,251,155$ & $649,225,116$ & $721,361,239$ & $1,370,586,355$ & $1,118,109,921$ \\
3 & $5,770,889,916$ & $577,088,992$ & $721,361,239$ & $1,298,450,231$ & $1,118,109,921$ \\
4 & $5,049,528,676$ & $504,952,868$ & $721,361,239$ & $1,226,314,107$ & $1,118,109,921$ \\
5 & $4,328,167,437$ & $432,816,744$ & $721,361,239$ & $1,154,177,983$ & $1,118,109,921$ \\
6 & $3,606,806,197$ & $360,680,620$ & $721,361,239$ & $1,082,041,859$ & $1,118,109,921$ \\
7 & $2,885,444,958$ & $288,544,496$ & $721,361,239$ & $1,009,905,735$ & $1,118,109,921$ \\
8 & $2,164,083,718$ & $216,408,372$ & $721,361,239$ & $937,769,611$ & $1,118,109,921$ \\
9 & $1,442,722,479$ & $144,272,248$ & $721,361,239$ & $865,633,487$ & $1,118,109,921$ \\
10 & $721,361,239$ & $72,136,124$ & $721,361,239$ & $793,497,363$ & $1,118,109,921$ \\
\hline \multicolumn{7}{r}{} & Total & $3,967,486,817$ & $7,213,612,395$ & $11,181,099,212$ & $11,181,099,212$ \\
\hline
\end{tabular}

Table 6 Total equity cost to investor (in Rupiah)

\begin{tabular}{crrrrr}
\hline Year & Investment & Interest & $\begin{array}{c}\text { Investment } \\
\text { Payment }\end{array}$ & Payment & $\begin{array}{c}\text { Annual } \\
\text { Payment }\end{array}$ \\
\hline 0 & $3,091,548,169$ & 0 & 0 & 0 & 0 \\
1 & $3,091,548,169$ & $340,070,299$ & $309,154,817$ & $649,225,116$ & $496,193,481$ \\
2 & $2,782,393,352$ & $306,063,269$ & $309,154,817$ & $615,218,086$ & $496,193,481$ \\
3 & $2,473,238,535$ & $272,056,239$ & $309,154,817$ & $581,211,056$ & $496,193,481$ \\
4 & $2,164,083,718$ & $238,049,209$ & $309,154,817$ & $547,204,026$ & $496,193,481$ \\
5 & $1,854,928,902$ & $204,042,179$ & $309,154,817$ & $513,196,996$ & $496,193,481$ \\
6 & $1,545,774,085$ & $170,035,149$ & $309,154,817$ & $479,189,966$ & $496,193,481$ \\
7 & $1,236,619,268$ & $136,028,119$ & $309,154,817$ & $445,182,936$ & $496,193,481$ \\
8 & $927,464,451$ & $102,021,090$ & $309,154,817$ & $411,175,907$ & $496,193,481$ \\
9 & $618,309,634$ & $68,014,060$ & $309,154,817$ & $377,168,877$ & $496,193,481$ \\
10 & $309,154,817$ & $34,007,030$ & $309,154,817$ & $343,161,847$ & $496,193,481$ \\
\hline \multicolumn{7}{r}{ Total } & $1,870,386,642$ & $3,091,548,169$ & $4,961,934,812$ & $4,961,934,812$ \\
\hline
\end{tabular}


Table 7 Total operational cost calculation without equity and depreciation

\begin{tabular}{lr}
\hline \multicolumn{1}{c}{ Component } & \multicolumn{1}{c}{ Cost/Year (Rp) } \\
\hline Raw Material & $55,752,213,000$ \\
Packaging & $5,815,804,500$ \\
Electricity & $937,904,503$ \\
Water & $61,877,118$ \\
Direct Labor & $1,294,920,000$ \\
Indirect Labor & $2,671,148,000$ \\
Worker Insurance & $49,660,680$ \\
Building and Plant Insurance & $60,869,568$ \\
Distribution Cost & $1,892,238,171$ \\
Marketing & $256,016,000$ \\
Operating Supplies & $90,644,400$ \\
Communication & $163,200,000$ \\
Maintenance Cost & $149,178,804$ \\
\hline Total & $69,195,674,744$ \\
\hline
\end{tabular}

Table 8 Total depreciation cost calculation

\begin{tabular}{cc}
\hline Year & Total Depreciation (in Rupiah) \\
\hline 1 & $318,951,022$ \\
2 & $288,857,504$ \\
3 & $262,923,034$ \\
4 & $241,530,853$ \\
5 & $221,156,570$ \\
6 & $204,354,320$ \\
7 & $189,744,980$ \\
8 & $177,006,174$ \\
9 & $165,863,723$ \\
10 & $156,084,468$ \\
\hline
\end{tabular}

Based on the calculated cash flow, we can analyze the plant's profitability by calculating minimum acceptable rate of return (MARR), internal rate of return (IRR), net present value (NPV), Payback Period, and rate of return (ROR). The results of the profitability analysis are shown in Table 12. The MARR shows the minimum value of ROR that is acceptable for starting a project, given its risk and opportunity cost (Park, 2007). Therefore, the IRR needs to surpass the MARR for the project to be categorized as a profitable project. Based on the calculation, the ROR and IRR obtained are $44.98 \%$ and $46 \%$, respectively, much higher than the MARR, which has a value of $8.19 \%$. The obtained payback period shows the number of years needed to return all the funds expended or to reach the break-even point (Farris et al., 2010). The obtained payback period of this plant is 2.24 years, which is considered average for an ice cream factory (Gunawan et al., 2020). The NPV determines the value of an investment over a period (Lin and Nagalingam, 2000). The NPV obtained is more than 21.8 billion rupiahs, which is more than twice the initial capital investment.

Compared to other studies, the results show that this plant is profitable and, in turn, can revitalize the local economy in the area where the plant is built. Gunawan et al. (2020) found that an ice cream factory built in East Java and using local ingredients resulted in only $17.28 \%$ ROR and had a more extended payback period of 4.65 years. On the other hand, a study by Almena et al. (2020) found that a distributed manufacturing ice cream factory can produce a $\$ 298.1 \mathrm{k}$ net profit per year. Meanwhile, our factory can produce a $\mathrm{Rp}$ $5,148,481,511.59$, or about $\$ 349.7 \mathrm{k}$, net profit per year. Therefore, we can conclude that this factory is feasible to build. 
Table 9 Profitability analysis

\begin{tabular}{lr}
\hline \multicolumn{1}{c}{ Component } & \multicolumn{1}{c}{ Value } \\
\hline MARR & $8.19 \%$ \\
IRR & $46 \%$ \\
NPV (in Rupiah) & $21,819,500,900$ \\
Payback Period & 2.24 years \\
ROR & $44.98 \%$ \\
\hline
\end{tabular}

\section{Conclusions}

Healthy herbal ice cream made out of Gynura procumbens can be a solution to improve public health, provide a healthier snacking alternative, and improve the national economy. The profitability analysis shows that the plant has a relatively short payback period, favorable break-even point, and feasible other costs. The payback period of the plant is 2.24 years. ROR and IRR obtained from this plant are 44.98 and $46 \%$, respectively. The NPV of this plant is Rp21,819,500,900.

\section{Acknowledgements}

The authors are grateful for the financial support of the present study by the Ministry of Research Technology and Higher Education through PDUPT (NKB1646/UN2.R3.1/HKP.00/2019).

\section{References}

Abrika, O.S.S., Yam, M.F., Asmawi, M.Z., Sadikun, A., Dieng, H., Hussain, E.A., 2013. Effects of Extracts and Fractions of Gynura Procumbens on Rat Atrial Contraction. Journal of Acupuncture and Meridian Studies, Volume 6(4), pp. 199-207

Almena, A., Fryer, P., Bakalis, S., Lopez-Quiroga, E., 2020. Local and Decentralised Scenarios for Ice-Cream Manufacture: A Model-Based Assessment at Different Production Scales. Journal of Food Engineering, Volume 286, pp. 1-12

Aritonang, K., Nainggolan, M., Djunaidi, A.V., 2020. Integrated Supply Chain for a Single Vendor and Multiple Buyers and Products with Crashing Lead Time. International Journal of Technology, Volume 11(3), pp. 642-651

Canadean, 2015. Ice Cream Market in Indonesia. Report CS1940MF, Consumer and Market Insights, Global Data, Jakarta, Indonesia

Ciptadana Sekuritas Asia, 2018. Equity Research: Unilever Indonesia (UNVR). Available Online at http://ciptadanasecurities.com/system/researches/files/000/000/329/original/KI_UNVR_20180122 .pdf, Accessed on May, 2020

Chou, T.C., Tobias, J., 1960. Quantitative Determination of Carbohydrates in Ice Cream by Paper Chromatography. Journal of Dairy Science, Volume 43(8), pp. 1031-1041

Farris, P.W., Bendle, N.T., Pfeifer, P.T., Reibstein, D.J., 2010. Marketing Metrics: The Definitive Guide to Measuring Marketing Performance. Upper Saddle River, New Jersey: Pearson Education, Inc.

Guinard, J.X., Zoumas-Morse, C., Mori, L., Panyam, D., Kilara, A., 1996. Effect of Sugar and Fat on the Acceptability of Vanilla Ice Cream. Journal of Dairy Science, Volume 79(11), pp. 1922-1927

Gunawan, I.R., Pasaribu, A.G.M., Prawiro, M., 2020. Perencanaan Pengolahan Es Krim Coklat dan Vanilla dalam Kemasan Cup dengan Kapasitas Produk 2200 liter/hari di Pandaan Jawa Timur (Planning for Processing Chocolate and Vanilla Ice Cream in Cup Packs with 
a Product Capacity of 2200 liters/day in Pandaan, East Java). Technical Report for Perencanaan Unit Pengolahan Pangan (Food Processing Unit Planning), Widya Mandala Catholic University, Surabaya, Indonesia

Harahap, A., Ramadhan, M., Lestari, T., Gozan, M., Srinophakun, P., 2019. Preliminary Plant Design of Biofuel from Algae in Balikpapan, East Kalimantan. In: IOP Conference Series: Earth and Environmental Science, Volume 353, pp. 1-8

Hidayat, N., Hidayat, A.N., Gozan, M., 2019. Preliminary Design of Corncob-Based Furfural Plant. In: AIP Conference Proceedings, Volume 2062(1), pp. 1-10

Hoe, S.Z., Lee, C.N., Mok, S.L., Kamaruddin, M.Y., Lam, S.K., 2011. Gynura Procumbens Merr. Decreases Blood Pressure in Rats by Vasodilatation Via Inhibition of Calcium Channels. Clinics, Volume 66(1), pp. 143-150

Iskander, M., Song, Y., Coupar, I., Jiratchariyakul, W., 2002. Anti-Inflammatory Screening of the Medicinal Plant Gynura Procumbens. Plant Foods for Human Nutrition, Volume 57(3-4), pp. 233-244

Kaur, N., Awadh, A.I., Ali, R.B., Sadikun, A., Sattar, M.Z.B.A., Asmawi, M.Z.B., 2012. CardioVascular Activity of Gynura Procumbens Merr. Leaf Extracts. International Journal of Pharmaceutical Sciences and Research, Volume 3(5), pp. 1401-1405

Kusrini, E., Kartohardjono, S., 2019. Revolutions in Chemical Engineering Through the Development of Materials Science and Product Design for Sustainable Energy and Future Applications. International Journal of Technology, Volume 10(3), 438-442

Lin, G.C.I., Nagalingam, S.V., 2000. CIM Justification and Optimisation. $1^{\text {st }}$ Edition. London: Taylor \& Francis

Marshall, R.T., Goff, H., Hartel, R., 2012. Ice Cream, 7th Edition. New York, US: Springer Publishing

Maw, S.S., Mon, M.M., Oo, Z.K., 2011. Study on Antioxidant and Antitumor Activities of Some Herbal Extracts. International Journal of Pharmacological and Pharmaceutical Sciences, Volume 75, pp. 450-455

Morelli's Gelato, 2017. The Difference Between Gelato and Ice Cream. Available Online at: https://morellisgelato.com/the-difference-between-gelato-and-ice-cream, Accessed on May 20, 2020

Mou, K.M., Dash, P.R., 2016. A Comprehensive Review on Gynura Procumbens Leaves. International Journal of Pharmacognosy, Volume 3(4), pp. 167-174

Park, C.S., 2007. Contemporary Engineering Economics. $4^{\text {th }}$ Edition. London: Pearson Publishing

Patel, M.R., Baer, R.J., Acharya, M.R., 2006. Increasing the Protein Content of Ice Cream. Journal of Dairy Science, Volume 89(5), pp. 1400-1406

Rosyidi, C.N., Fatmawati, A., Jauhari, W.A., 2016. An Integrated Optimisation Model for Product Design and Production Allocation in a Make to Order Manufacturing System. International Journal of Technology, Volume 7(5), 819-830

Soukoulis, C., Lebesi, D., Tzia, C., 2009. Enrichment of Ice Cream with Dietary Fibre: Effects on Rheological Properties, Ice Crystallisation and Glass Transition Phenomena. Food Chemistry, Volume 115(2), pp. 665-671

Sudarto, B., Pramono, S., 1985. Phytochemical Screening of Dewa Leaves (Gynura Procumbens. Lour Merr) Which is Thought to Have Anti-Cancer Properties, PPPTUGM, Lembaga Penelitian UGM, Yogyakarta. (Unpublished)

Surya, E., Rahman, S., Zulamraini, S. Gozan, M., 2018. Preliminary Plant Design of Escherichia Coli BPPTCC-Egrk2 Cell Culture for Recombinant Cellulase Production using Oil Palm Empty Fruit Bunch (OPEFB) as Substrate. In: IOP Conference Series: Earth and Environmental Science, Volume 141, pp. 1-10 
United States Department of Agriculture (USDA), 2019. Agricultural Research Service, FoodData Central: Vanilla Ice Cream Nutrients. Available Online at https://ndb.nal.usda.gov/fdc-app.html\#/food-details/167575/nutrients, Accessed on August 18, 2020

United States Geological Service (USGS), 2016. Water Q\&A: How Much Water Do I Use at Home Each Day? Available Online at https://water.usgs.gov/edu/qa-homepercapita.html, Accessed on August 18, 2020 